\title{
Daya saing sektor pertanian dalam mendorong pembangunan pertanian di Provinsi Jambi
}

\author{
Yulmardi*; Erfit \\ Prodi Ekonomi Pembangunan Fakultas Ekonomi dan Bisnis Universitas Jambi \\ *E-mail korespondensi: Yulmardi@unja.ac.id
}

\begin{abstract}
This study aims to look at the level of competitiveness of Jambi province in the agricultural sector and the necessary policy to increase competitiveness. The results of the study found that in large scale Jambi province has relatively high enough competitiveness in the agricultural sector, it can be seen from $L Q$ coefficient of the agricultural sector is superior to one, especially in the fields of plantation and horticulture. Then, in the micro some commodities that potentially have relatively high competitiveness such as soybean, potato, chili, coffee and coconut commodities, especially if we look at the level of productivity, while rubber and palm oil mainly in terms of land area and production level. Then based on the SWOT analysis for the agricultural sector, it seems that the agricultural sector has the potential and opportunity to be developed in the future, which has obstacles and threats to the development of the agricultural sector. In order to increase the competitiveness of the agricultural sector for Jambi province, various policies were carried out including through improvement in terms of farmers' capabilities, institutions, productivity, production and cluster approaches.
\end{abstract}

Keywords: Competitiveness, SWOT, Agricultural development

\begin{abstract}
Abstrak
Penelitian ini bertujuan untuk melihat tingkat daya saing Provinsi Jambi untuk sektor pertanian dan kebijakan yang diperlukan untuk peningkatan daya saing. Hasil penelitian menunjukkan bahwa secara makro Provinsi Jambi relatif memiliki daya saing yang cukup tinggi untuk sektor pertanian, terlihat dari koefisien LQ sektor pertanian yang lebih besar dari satu, terutama untuk bidang perkebunan dan hortikultura. Kemudian secara mikro beberapa komoditi yang secara potensial memiliki daya saing yang relatif tinggi diantaranya komoditi kedelai,kentang, cabai, kopi dan kelapa terutama jika kita lihat dari sisi tingkat produktivitas, sementara karet dan kelapa sawit terutama dilihat dari sisi luas lahan dan tingkat produksi. Selanjutnya berdasarkan analisa SWOT untuk sektor pertanian, terlihat sektor pertanian memiliki potensi dan peluang untuk dikembangkan dimasa yang akan datang, yang memiliki hambatan dan ancaman untuk pengembangan untuk sektor pertanian tersebut. Dalam rangka peningkatan daya saing sektor pertanian untuk Provinsi Jambi dilakukan berbagai kebijakan diantaranya melalui peningkatan dari segi kemampuan petani, kelembagaan, produktivitas, produksi dan pendekatan klaster.
\end{abstract}

Kata kunci: Daya saing, SWOT, Pembangunan Pertanian 


\section{PENDAHULUAN}

Sampai saat ini bagi Provinsi Jambi sektor pertanian juga masih merupakan sektor prioritas dalam pembangunan. Keadaan ini dapat kita lihat dari cukup besarnya sumbangan sektor pertanian terhadap perekonomian Provinsi Jambi terutama dilihat dari sumbangannya terhadap PDRB. Dari data yang ada sektor pertanian telah menyumbang sekitar 17,47 persen terhadap PDRB Provinsi Jambi (Badan Pusat Statistik, 2015). Disamping itu sektor pertanian juga telah dapat menyerap tenaga kerja dalam jumlah yang relatif besar. Relatif besarnya peranan dari sektor pertanian ini terhadap perekonomian Provinsi Jambi tentu tidak terlepas dari potensi yang dimiliki oleh Provinsi Jambi disektor pertanian baik dilihat ketersediaan lahan yang cukup luas dan kondisi agroklimat yang dimiliki. Bila kita amati lebih jauh potensi ini tersebar hampir diseluruh kabupaten yang ada di Provinsi Jambi. Melihat peranan dari sektor pertanian terhadap perekonomian dan potensi yang dimiliki disektor pertanian ini, maka upaya pembangunan pertanian masih perlu dilanjutkan dan ditingkatkan dimasa yang akan datang.

Dalam rangka mendorong pembangunan pertanian sektor pertanian untuk provinsi dimasa yang akan datang maka sektor pertanian tidak cukup hanya dilihat dari sekedar potensi yang dimiliki saja tetapi juga harus dilihat dari kemampuan dari sektor pertanian Provinsi Jambi dibandingkan dengan berbagai daerah lain dalam hal ini menyangkut daya saing. Secara umum daya saing (competitiveness) dapat diartikan sebagai kemampuan untuk bersaing (Abdullah et all, 2002). Sementara itu Bank Dunia mengartikan daya saing sebagai besaran serta laju perubahan nilai tambah input yang dapat dicapai oleh perusahaan. Kemudian Porter (1990) menjelaskan bahwa konsep daya saing yang dapat diterapkan pada level nasional tak lain adalah produktivitas yang diartikan sebagai nilai output yang dihasilkan oleh seorang tenaga kerja. Berkaitan dengan daya sektor pertanian hasil penelitian Saptana (2010) menyimpulkan bahwa masih rendahnya daya saing komoditi padi atau beras pada beberapa sentra produksi beras di Indonesia. Lebih lanjut dijelaskan bahwasanya daya saing untuk komoditi sayuran cukup tinggi. Berdasarkan berbagai uraian diatas penelitian ini bertujuan untuk menganalisis daya saing sektor pertanian Provinsi Jambi dan kebijakan-kebijakan dalam rangka meningkatkan daya saing sektor pertanian tersebut.

\section{METODE}

Data yang digunakan sebagai dasar dalam analisis adalah data sekunder. Data sekunder yang dikumpulkan meliputi data PDRB Provinsi Jambi, penyerapan tenaga kerja sektor pertanian, investasi sektor pertanian, ekspor Provinsi Jambi yang berasal dari sektor pertanian, dan berbagai kebijakan disektor pertanian dalam rangka mendorong daya saing sektor pertanian Provinsi Jambi. Data diperoleh dari berbagai instansi terkait yang berhubungan dengan topik penelitian yang dilakukan diantaranya: BPS Provinsi Jambi, Bappeda Provinsi Jambi, Dinas pertanian tanaman pangan Provinsi Jambi, Dinas perdagangan dan berbagai instansi terkai lainnya lainnya.

Daya saing sektor pertanian dianalisis secara deskriptif serta menggunakan analisis Location Quotient (LQ). Selanjutnya untuk merumuskan kebijakan-kebijakan dalam rangka meningkatkan daya saing sektor pertanian digunakan analisis SWOT (Strenght, Weakness, Opportunities dan Threat). 


\section{HASIL DAN PEMBAHASAN}

\section{Daya saing sektor pertanian Provinsi Jambi}

Secara umum daya saing sektor dapat dilihat dari berbagai aspek, diantaranya keunggulan, tingkat produksi dan produktivitas. Berikut akan dijelaskan berbagai aspek tersebut yang dapat mendeskripsi daya saing dari sektor pertanian Provinsi Jambi.

\section{Analisis ekonomi basis}

Salah satu metode yang sering digunakan untuk melihat peranan suatu sektor terhadap perekonomian sauatu daerah/wilayah termasuk sektor pertanian yaitu analisis ekonomi basis. Dalam hal ini perekonomian atau sektor disuatu wilayah dibagi menjadi 2 yaitu sektor basis dan non basis. Dalam hal ini apabila suatu sektor merupakan sektor basis menunjukkan bahwa wilayah tersebut dalam menghasil suatu komoditi tidak saja dapat memenuhi kebutuhan untuk penduduk diwilayah yang bersangkutan tetapi juga dapat diekspor ke wilayah lain dan sebaliknya.

Salah satu metode yang digunakan untuk penentuan sektor basis atau nonbasis bagi perekonomian suatu wilayah adalah analisis Location Qoutient (LQ). Nilai koefisien LQ tersebut bisa $>1$ atau $<1$. Apabila nilai LQ dari sektor perekonomian disuatu wilayah nilai koefisien LQ nya $>1$ maka sektor tersebut merupakan sektor basis dan sektor tersebut memiliki keunggulan komparatif serta memiliki daya saing yang cuku tinggi pada sektor teretentu. Berikut ini dapat kita lihat posisi dari sektor pertanian dalam perekonomian Provinsi Jambi.

Tabel 1. Koefisien location qoutient (LQ) sektor pertanian Provinsi Jambi

\begin{tabular}{clcccc}
\hline No & Sektor/Subsektor & $\mathbf{2 0 1 2}$ & $\mathbf{2 0 1 3}$ & $\mathbf{2 0 1 4}$ & Rata-rata \\
\hline 1. & Pertanian & 2,42 & 1,92 & 1,97 & 2,10 \\
2. & Tanaman Pangan & 0,67 & 0,73 & 0,77 & 0,72 \\
3. & Hortikultura & 2,11 & 2,18 & 2,20 & 2,16 \\
4. & Perkebunan & 3,75 & 3,68 & 3,72 & 3,75 \\
5. & Peternakan & 0,82 & 0,79 & 0,87 & 0,83 \\
\hline
\end{tabular}

Sumber: Statistik pertanian,2014 (diolah)

Dari Tabel 1 memperlihatkan nilai LQ sektor pertanian untuk periode 2012 2014 Provinsi Jambi lebih besar dari 1 dimana hal ini menunjukkan bahwasanya sektor pertanian sektor pertanian tersebut merupakan sektor basis bagi perekonomian Provinsi Jambi. Dengan kata lain dalam produksi sektor pertanian tidak saja dapat memenuhi kebutuhannnya sendiri tetapi juga dapat di ekspor ke daerah lain. Dalam perspektif daya saing hasil tersebut menunjukkan sektor pertanian pada dasarnya memiliki daya saing yang cukup tinggi. Relatif tingginnya daya saing sektor pertanian ini bagi Provinsi Jambi tidak terlepas dari potensi yang dimiliki oleh Provinsi Jambi untuk sektor pertanian baik dilihat dari sisi ketersediaan lahan pertanian yang cukup luas juga didukung oleh kondisi agroklimat yang memungkinkan untuk tumbuhnya berbagai komodti pertanian di Provinsi Jambi. Bila kita kita amati lebih jauh secara geografis potensi tersebut tersebar diberbagai kabupaten yang ada di Provinsi Jambi. Keadaan ini dapat kita lihat sektor pertanian itu merupakan sektor basis atau sektor unggulan bagi perekonomian untuk semua kabuapaten yang ada di Provinsi Jambi (Erfit, 2000).

Kemudian jika dilihat lebih lanjut dari subsektor pertanian yang ada subsektor hortikultura dan perkebunan juga merupakan sektor basis bagi perekonomian Provinsi Jambi. Hal ini ditunjukkan oleh nilai LQ untuk subsektor hortikultura dan perkebunan lebih besar dari 1. Keadaan ini menunjukkan bahwasanya subsektor pangan dan subsektor perkebunan merupakan subsektor unggulan bagi perekonomian Provinsi Jambi yang pada gilirannya subsektor hortikultura dan perkebunan merupakan 
subsektor yang memiliki daya saing yang cukup tinggi bagi perekonomian Provinsi Jambi. Dijadikannya subsektor hortikultura dan perkebunan sebagai subsektor yang memiliki daya saing cukup tinggi tidak terlepas dari potensi yang dimiliki oleh Provinsi Jambi untuk kedua subsektor tersebut terutama subsektor perkebunan. Seperti halnya pada sektor pertanian dalam arti luas, maka subsektor perkebunan tersebut juga merupakan sektor basis disemua kabupaten yang ada di Provinsi Jambi (Erfit, 2000).

\section{Produktivitas sektor pertanian}

Disamping menggunakan koefisien lokasi (LQ) sebagai penentu daya saing sekor pertanian di Provinsi Jambi, beberapa hal yang berkaitan dengan luas lahan, jumlah produksi dan tingkat produktivitas suatu komoditi dapat juga dijadikan sebagai indikator daya saing. Berikut ini akan diberikan gambaran berkaitan dengan hal tersebut untuk beberapa komoditi penting yang dapat memberikan gambaran daya saing Provinsi Jambi untuk sektor pertanian.

\section{Padi}

Provinsi Jambi memiliki tingkat produktivitas padi yang lebih rendah dibandingkan tingkat produktivitas secara nasional. Pada tahun 2013 tingkat produktivitas untuk padi secara nasional itu adalah 51,52 Ku/Ha, sementara Provinsi Jambi hanya sekitar 43,36 Ku/Ha.

Bila diamati lebih lanjut untuk wilayah Sumatera, tingkat produktivitas padi untuk Provinsi Jambi masih berada dibawah provinsi Lampung, Sumatera Utara, Sumatera Barat, Aceh dan Sumatera Selatan. Demikian juga halnya dari sisi lain seperti dari luas lahan dan tingkat produksi padi Provinsi Jambi secara umum masih di bawah beberapa provinsi lainnya di wilayah Sumatera. Kondisi ini dalam kontek daya saing untuk tanaman padi Provinsi Jambi relatif lebih rendah dibandingkan dengan beberpa provinsi lain di wilayah Sumatera.

Tabel 2 secara terperinci memberikan kondisi luas lahan, produksi, dan produktivitas tanaman padi provinsi-provinsi yang ada di wilayah Sumatera.

Tabel 2. Luas lahan, produksi dan tingkat produktivitas padi provinsi-provinsi di Sumatera Tahun 2013

\begin{tabular}{clccc}
\hline No & \multicolumn{1}{c}{ Provinsi } & Luas Lahan (Ha) & Produksi (Ton) & $\begin{array}{c}\text { Produktivitas } \\
(\mathbf{K u} / \mathbf{H a})\end{array}$ \\
\hline 1. & Aceh & 419.183 & 1.956 .940 & 46,68 \\
2. & Sumatera Utara & 742.968 & 3.727 .249 & 50,17 \\
3. & Sumatera Barat & 487.820 & 2.430 .384 & 49,82 \\
4. & Riau & 118.518 & 434.144 & 36,63 \\
5. & Kepulauan Riau & 379 & 1.370 & 36,15 \\
6. & Jambi & 153.243 & 664.535 & 43,36 \\
7. & Sumatera Selatan & 800.036 & 3.676 .723 & 45,96 \\
8. & Kep. Bangka Belitung & 10.232 & 28.480 & 27,83 \\
9. & Bengkulu & 147.680 & 622.832 & 42,17 \\
10 & Lampung & 638.090 & 3.207 .002$. & 50,26 \\
\hline & Indonesia & 13.835 .252 & 71.279 .709 & 51,52 \\
\hline
\end{tabular}

Sumber: Statistik pertanian,2014 (diolah)

\section{Jagung}

Seperti halnya dengan tanaman padi, produktivitas jagung di Provinsi Jambi juga lebih rendah dibandingkan dengan tingkat produktivitas jagung secara nasional. Dari data yang ada pada tahun 2013 terlihat tingkat produktivitas secara nasional adalah 48,44 Ku/Ha, sementara Provinsi Jambi hanya sekitar 39,50 Ku/Ha. Produktivitas provinsi untuk jagung masih berada dibawah beberapa provinsi yang ada di wilayah 
Sumatera. Provinsi Jambi masih dibawah provinsi Sumatera Barat, Sumatera Utara, Bengkulu, Sumatera Selatan dan Lampung. Demikian juga halnya dengan luas lahan dan tingkat produksi untuk jagung Provinsi Jambi masih berada dibawah beberapa provinsi yang ada di Sumatera. Dalam kaitannya dengan tingkat daya saing untuk tanaman jagung Provinsi Jambi relatif rendah jika dibandingkan dengan beberapa provinsi yang ada di wilayah Sumatera. Demikian juga dari sisi luas lahan dan tingkat produksi Provinsi Jambi untuk tanaman jagung masih berada dibawah beberapa provinsi lainnya di wilayah Sumatera.

Tabel 3 memberikan kondisi Provinsi Jambi untuk tanaman jagung dan perbandingannya dengan berbagai provinsi lain yang ada di wilayah Sumatera.

Tabel 3. Luas lahan, produksi dan tingkat produktivitas jagung provinsi-provinsi di Sumatera Tahun 2013

\begin{tabular}{clccc}
\hline No & Provinsi & Luas Lahan (Ha) & Produksi (Ton) & $\begin{array}{c}\text { Produktivitas } \\
(\text { Ku/Ha) }\end{array}$ \\
\hline 1. & Aceh & 44.099 & 177.842 & 40,33 \\
2. & Sumatera Utara & 211.750 & 1.183 .011 & 55,87 \\
3. & Sumatera Barat & 81.665 & 547.417 & 67,03 \\
4. & Riau & 11.748 & 28.052 & 23,88 \\
5. & Kepulauan Riau & 339 & 790 & 23,30 \\
6. & Jambi & 6.504 & 25.690 & 39,50 \\
7. & Sumatera Selatan & 32.558 & 167.457 & 51,43 \\
8. & Kep. Bangka Belitung & 234 & 783 & 33,46 \\
9. & Bengkulu & 18.257 & 93.988 & 51,48 \\
10 & Lampung & 346.315 & 1.760 .278 & 50,83 \\
\hline & Indonesia & 3.821 .504 & 18.511 .853 & 48,44 \\
\hline
\end{tabular}

Sumber: Statistik pertanian,2014 (diolah)

\section{Kedelai}

Dilihat dari sisi produktivitas untuk tanaman kedelai, Provinsi Jambi memiliki tingkat produktivitas yang relatif lebih tinggi dibandingkan dengan produktivitas jagung ditingkat nasional. Berdasarkan Tabel 4 menunjukkan bahwa produktivitas kedelai untuk tingkat nasional adalah sebesar 14,16 Ku/Ha sementara provins Jambi memiliki tingkat produktivitas $14,42 \mathrm{Ku} / \mathrm{Ha}$. Namun demikian bila kita amati lebih lanjut dari sisi luas lahan yang dimiliki dan produksi untuk tanaman kedelai ini Provinsi Jambi secara relatif masih berada dibawah beberapa provinsi lain di wilayah Sumatera.

Tabel 4. Luas lahan, produksi dan tingkat produktivitas kedelai provinsi-provinsi di Sumatera Tahun 2013

\begin{tabular}{llccc}
\hline No & Provinsi & Luas Lahan $(\mathbf{H a})$ & Produksi (Ton) & $\begin{array}{c}\text { Produktivitas } \\
(\mathbf{K u} / \mathbf{H a})\end{array}$ \\
\hline 1. & Aceh & 30.579 & 45.027 & 14,72 \\
2. & Sumatera Utara & 3.126 & 3.229 & 10,33 \\
3. & Sumatera Barat & 690 & 732 & 10,61 \\
4. & Riau & 1.949 & 2.211 & 11,34 \\
5. & Kepulauan Riau & 17 & 18 & 12.64 \\
6. & Jambi & 1.877 & 2.372 & 14,42 \\
7. & Sumatera Selatan & 3.564 & 5.140 & 10,72 \\
8. & Kep.Bangka Belitung & - & - & - \\
9. & Bengkulu & 3.720 & 3.987 & 12,35 \\
10 & Lampung & 4.986 & 6.156 & 10,59 \\
\hline & Indonesia & 550.793 & 779.992 & 14,16 \\
\hline
\end{tabular}

Sumber: Statistik pertanian,2014 (diolah) 


\section{Kentang}

Dari sisi produktivitas untuk tanaman kentang, seprti halnya untuk tanaman kedelai secara relatif juga memiliki produktivitas yang relatif tinggi dibandingkan dengan produktivitas nasional. Dari data yang ada pada tahun 2013 tingkat produktivitas tanaman kentang secara nasional adalah 16,02 Ku/H

Tabel 2 secara terperinci memberikan kondisi luas lahan, produksi, dan produktivitas tanaman kentang provinsi-provinsi yang ada di wilayah Sumatera.

Tabel 5. Luas lahan, produksi dan produktivitas kentang provinsi-provinsi di di Sumatera Tahun 2013

\begin{tabular}{clrrr}
\hline No & Provinsi & Luas lahan (Ha) & Produksi (Ton) & $\begin{array}{c}\text { Produktivitas } \\
(\text { Ku/Ha) }\end{array}$ \\
\hline 1. & Aceh & 692 & 11.310 & 16,34 \\
2. & Sumatera Utara & 5.633 & 100.736 & 17,88 \\
3. & Sumatera Barat & 2.670 & 44.669 & 16,73 \\
4. & Riau & - & - & - \\
5. & Kepulauan Riau & - & - & - \\
6. & Jambi & 4.527 & 75.512 & 16,68 \\
7. & Sumatera Selatan & 121 & 2.823 & 23,33 \\
8. & Kep. Bangka Belitung & - & - & - \\
9. & Bengkulu & 868 & 12.830 & 14,78 \\
10 & Lampung & 47 & 665 & 14,14 \\
\hline \multicolumn{2}{r}{ Indonesia } & $\mathbf{7 0 . 1 8 7}$ & $\mathbf{1 . 1 2 4 . 2 8 2}$ & $\mathbf{1 6 , 0 2}$ \\
\hline
\end{tabular}

Sumber: Statistik pertanian,2014 (diolah)

Sementara tingkat produktivitas Provinsi Jambi mencapai 16,68. Bila kita amati lebi jauh dari sisi luas lahan dan produksi tanaman kentang Provinsi Jambi juga mempunyai potensi yang cukup besar di wilayah terutama jika kita bandingkan dengan beberapa rovinsi yang ada di Sumatera. Dari sisi luas lahan dan produksi Provinsi Jambi berda diurutan kedua setelah Sumatera Utara.

Namun demikian yang perlu menjadi perhatian untuk komoditi kentang ini Provinsi Jambi masih tertinggal jika dibandingkan dengan beberapa sentra produksi utama untuk komoditi kentang yang ada di di wilayah pulau Jawa terutama Jawa Barat, Jawa Tengah dan Jawa Timur. Berikut dari Tabel 5 berikut ini dapat kita lihat secara lebih lengkap berkaitan dengan kondisi Provinsi Jambi untuk komoditi kentang ini.

\section{Cabai}

Dari sisi produktivitas untuk tanaman cabai, Provinsi Jambi memiliki tingkat produktivitas yang relatif tinggi dibandingkan dengan produktivas tanaman cabai ditingkat naional. Dari data yang ada pada tahun 2013 tingkat produktivitas untuk tanaman cabai ditingkat nasional adalah 8,16 Ku/Ha, sementara Provinsi Jambi mencapai $11,23 \mathrm{Ku} / \mathrm{Ha}$. Namun dilihat dari sisi luas lahan dan tingkat produksi Provinsi Jambi masih relatif tertinggal dibandingkan dengan berbagai provinsi yang ada di wilayah Sumatera.

Dalam kaitannya dengan daya saing dilihat dari tingkat produktivitas untuk komoditi cabe ini cukup tinggi bagi Provinsi Jambi, maka secara potensial dapat kita katakan komoditi cabe memiliki daya saing yang cukup tinggi bagi Provinsi Jambi. Luas lahan, produksi dan tingkat produktivitas cabai provinsi-provinsi di Pulau Sumatera secara terperinci diberikan pada Tabel 6 berikut. 
Tabel 6. Luas lahan, produksi dan tingkat produktivitas cabai provinsi-provinsi di di Sumatera Tahun 2013

\begin{tabular}{llccc}
\hline No & \multicolumn{1}{c}{ Provinsi } & Luas Lahan (Ha) & Produksi (Ton) & $\begin{array}{c}\text { Produktivitas } \\
(\mathbf{K u} / \mathbf{H a})\end{array}$ \\
\hline 1. & Aceh & 4.449 & 42.427 & 9,43 \\
2. & Sumatera Utara & 17.164 & 161.933 & 9,43 \\
3. & Sumatera Barat & 7.453 & 60.981 & 8,18 \\
4. & Riau & 1.848 & 9.089 & 4,92 \\
5. & Kepulauan Riau & 354 & 1.852 & 5,23 \\
6. & Jambi & 3.477 & 39.055 & 11,23 \\
7. & Sumatera Selatan & 6.011 & 15.109 & 2,51 \\
8. & Kep. Bangka Belitung & 431 & 3.636 & 8,44 \\
9. & Bengkulu & 5.791 & 40.001 & 6,91 \\
10 & Lampung & 5.500 & 35.233 & 6,41 \\
\hline & Indonesia & $\mathbf{1 2 4 . 1 1 0}$ & $\mathbf{1 . 0 1 2 . 8 7 9}$ & $\mathbf{8 , 1 6}$ \\
\hline
\end{tabular}

Sumber: Statistik Pertanian,2014 (diolah)

\section{Bawang merah}

Dilihat dari sisi produktivitas komoditi bawang merah, Provinsi Jambi memiliki tingkat produktivitas yang rendah dibandingkan tingkat prodkivias nasional. Dari data yang ada pada tahun 2013 tingkat produktivitas komoditi bawang merah ditingkat nasional adalah sebesar 10,22 Ku/Ha, sementara Provinsi Jambi hanya sebesar 4,74 $\mathrm{Ku} / \mathrm{Ha}$.

Demikian juga halnya dengan luas lahan dan tingkat produksi untuk komoditi bawang merah juga relatif tertinggal dibandingkan dengan beberapa provinsi lainnya di wilayah Sumatera. Dalam kaitannya dengan daya saing, maka kondisi ini memperlihatkan rendahnya tingkat daya saing Provinsi Jambi terhadap komoditi bawang merah ini.

Tabel 7 secara terperinci memberikan kondisi luas lahan, produksi, dan produktivitas tanaman bawang merah provinsi-provinsi yang ada di wilayah Sumatera.

Tabel 7. Luas lahan, produksi dan tingkat produktivitas bawang merah provinsi-provinsi di Sumatera

\begin{tabular}{llccc}
\hline No & Provinsi & Luas Lahan (Ha) & Produksi (Ton) & $\begin{array}{c}\text { Produktivitas } \\
(\mathbf{K u} / \mathbf{H a})\end{array}$ \\
\hline 1. & Aceh & 547 & 3.711 & 6,78 \\
2. & Sumatera Utara & 1.048 & 8.305 & 7,92 \\
3. & Sumatera Barat & 4.144 & 42.791 & 10,33 \\
4. & Riau & 3 & 12 & 4,00 \\
5. & Kepulauan Riau & - & - & - \\
6. & Jambi & 213 & 1.010 & 4,74 \\
7. & Sumatera Selatan & 30 & 218 & 7,26 \\
8. & Kep. Bangka Belitung & - & - & - \\
9. & Bengkulu & 116 & 699 & 6,02 \\
10 & Lampung & 24 & 220 & 9,18 \\
\hline & Indonesia & $\mathbf{9 8 . 9 3 7}$ & $\mathbf{1 . 0 1 0 . 7 3 3}$ & $\mathbf{1 0 , 2 2}$ \\
\hline
\end{tabular}

Sumber: Statistik pertanian,2014 (diolah)

\section{$\underline{\text { Karet }}$}

Dari sisi produktivitas untuk komoditi karet, Provinsi Jambi memiliki tingkat produktivitas yang rendah dibandingkan dengan tingkat produktivitas nasional. Dari data yang ada pada tahun 2013 tingkat produksi komoditi karet secara nasional adalah $1.083 \mathrm{Kg} / \mathrm{Ha}$, sementara Provinsi Jambi hanya sebesar $858 \mathrm{Kg} / \mathrm{Ha}$. 
Tabel 8. Luas lahan, produksi dan tingkat produktivitas karet provinsi-provinsi di Sumatera Tahun 2013

\begin{tabular}{llccc}
\hline No & \multicolumn{1}{c}{ Provinsi } & Luas Lahan (Ha) & Produksi (Ton) & $\begin{array}{c}\text { Produktivitas } \\
\text { (Kg/Ha) }\end{array}$ \\
\hline 1. & Aceh & 113.525 & 74.793 & 916 \\
2. & Sumatera Utara & 472.299 & 448.968 & 1.061 \\
3. & Sumatera Barat & 129.260 & 120.980 & 993 \\
4. & Riau & 356.584 & 324.207 & 1.049 \\
5. & Kepulauan Riau & 32.467 & 20.12 & 1.103 \\
6. & Jambi & 385.233 & 270.247 & 858 \\
7. & Sumatera Selatan & 810.780 & 932.502 & 1.316 \\
8. & Kep. Bangka Belitung & 44.351 & 41.149 & 1.133 \\
9. & Bengkulu & 94.977 & 93.328 & 1.238 \\
10 & Lampung & 91.553 & 66.862 & 959 \\
\hline & Indonesia & $\mathbf{3 . 5 5 5 . 9 4 6}$ & $\mathbf{3 . 2 3 7 . 4 3 3}$ & $\mathbf{1 . 0 8 3}$ \\
\hline
\end{tabular}

Sumber: Statistik Pertanian,2014 (diolah)

Namun bila kita amati lebih lanjut maka terlihat dari sisi luas lahan yang ada dan tingkat produksi komoditi karet cuku tinggi jika dibandingkan dengan beberapa provinsi lainnya di wilayah Sumatera. Dengan demikian dalam kaitannya dengan daya saing dilihat dari luas lahan dan tingkat produksi komoditi karet secara potensial adalah relatif tinggi. Berikut ini Tabel 8 dapat kita lihat kondisi komoditi karet untuk Provinsi Jambi dan perbandingannya dengan povinsi lain di wilayah Sumatera.

\section{Kelapa sawit}

Dari sisi produktivitas untuk komoditi kelapa sawit, seperti halnya dengan komoditi karet, Provinsi Jambi memiliki tingkat produktivitas yang rendah dibandingkan dengan tingkat produktivitas nasional.

Tabel 9. Luas lahan, produksi dan produktivitas kelapa sawit provinsi-provinsi di Sumatera Tahun 2013

\begin{tabular}{llrcc}
\hline No & \multicolumn{1}{c}{ Provinsi } & Luas Lahan (Ha) & Produksi (Ton) & $\begin{array}{c}\text { Produktivitas } \\
\text { (Kg/Ha) }\end{array}$ \\
\hline 1. & Aceh & 396.644 & 817.525 & 3.006 \\
2. & Sumatera Utara & 1.340 .348 & 4.549 .202 & 4.101 \\
3. & Sumatera Barat & 364.208 & 1.022 .332 & 3.470 \\
4. & Riau & 2.193 .721 & 6.646 .997 & 3.660 \\
5. & Kepulauan Riau & 19.036 & 36.774 & 2.117 \\
6. & Jambi & 657.929 & 1.749 .617 & 3.420 \\
7. & Sumatera Selatan & 1.060 .573 & 2.690 .620 & 3.411 \\
8. & Kep. Bangka Belitung & 201.091 & 508.125 & 3.391 \\
9. & Bengkulu & 290.633 & 787.050 & 3.693 \\
10 & Lampung & 158.045 & 424.054 & 3.382 \\
\hline & Indonesia & $\mathbf{1 0 . 4 6 5 . 0 2 0}$ & $\mathbf{2 7 . 7 8 2 . 0 0 4}$ & $\mathbf{3 . 5 3 6}$ \\
\hline
\end{tabular}

Sumber: Statistik Pertanian,2014 (diolah)

Berdasarkan Tabel 9, pada tahun 2013 tingkat produksi komoditi kelapa sawit secara nasional adalah $3.536 \mathrm{Kg} / \mathrm{Ha}$, sementara Provinsi Jambi hanya sebesar 3.420 $\mathrm{Kg} / \mathrm{Ha}$. Namun dari sisi luas lahan yang ada dan tingkat produksi komoditi kelapa sawit cukup tinggi jika dibandingkan dengan beberapa provinsi lainnya di wilayah Sumatera. Dengan demikian dalam kaitannya dengan daya saing dilihat dari luas lahan dan tingkat produksi komoditi kelapa sawit secara potensial adalah relatif tinggi. Berikut ini Tabel 
9 dapat kita lihat kondisi komoditi kelapa sawit untuk Provinsi Jambi dan perbandingannya dengan povinsi lain di wilayah Sumatera.

\section{Kopi}

Dari sisi produktivitas untuk komoditi kopi, Provinsi Jambi memiliki tingkat produktivitas yang tinggi jika dibandingkan dengan tingkat produktivita ditingkat nasional. Dari data yang ada pada tahun 2013 terlihat tingkat produktivitas nasional untuk komoditi kopi adalah sebesar $739 \mathrm{Kg} / \mathrm{Ha}$, sementara untuk Jambi adalah sebesar $812 \mathrm{Kg} / \mathrm{Ha}$ (Tabel 10). Namun demikian dari sisi luas lahan dan tingkat produksi provinsi relatif tertinggal dibandingkan provinsi lian yang ada di wilayah Sumatera. Berdasarkan Tabel 10 menunjukkan bahwa dari sisi luas lahan dan produksi Provinsi Jambi masih berada dibawah Sumatera Selatan, Aceh, Sumaera Utara, Lampung dan Bengkulu. Dalam kaitannya dengan daya saing sebenarnya secara potensial Provinsi Jambi memiliki daya sainga ynang cukup tinggi trhadap komoditi kopi ini.

Tabel 10. Luas lahan, produksi dan tingkat produktivitas kopi provinsi-provinsi di Sumatera Tahun 2013

\begin{tabular}{llrcr}
\hline No & \multicolumn{1}{c}{ Provinsi } & Luas Lahan (Ha) & Produksi (Ton) & $\begin{array}{c}\text { Produktivitas } \\
\text { (Kg/Ha) }\end{array}$ \\
\hline 1. & Aceh & 123.764 & 48.282 & 622 \\
2. & Sumatera Utara & 81.461 & 58.345 & 1.025 \\
3. & Sumatera Barat & 42.565 & 32.559 & 987 \\
4. & Riau & 5.415 & 2.601 & 717 \\
5. & Kepulauan Riau & 47 & 3 & 111 \\
6. & Jambi & 25.935 & 13.326 & 812 \\
7. & Sumatera Selatan & 249.417 & 139.788 & 683 \\
8. & Kep. Bangka Belitung & 27 & 3 & 200 \\
9. & Bengkulu & 90.884 & 56.450 & 748 \\
10 & Lampung & 161.240 & 127.073 & 886 \\
\hline & Indonesia & $\mathbf{1 . 2 4 1 . 8 3 6}$ & $\mathbf{6 7 5 . 9 1 5}$ & $\mathbf{7 3 9}$
\end{tabular}

Sumber: Statistik Pertanian,2014 (diolah)

\section{Kakao}

Komoditi kakao di Provinsi Jambi memiliki tingkat produktivitas yang lebih rendah jika dibandingkan nasional. Dari data yang ada pada tahun 2013 terlihat tingkat produktivitas nasional untuk komoditi kakao adalah sebesar $821 \mathrm{Kg} / \mathrm{Ha}$ (Tabel 11)

Tabel 11. Luas lahan, produksi dan tingkat produktivitas kakao provinsi-provinsi di Sumatera Tahun 2013

\begin{tabular}{clccc}
\hline No & \multicolumn{1}{c}{ Provinsi } & Luas Lahan (Ha) & Produksi (Ton) & $\begin{array}{c}\text { Produktivitas } \\
(\mathbf{K g} / \mathbf{H a})\end{array}$ \\
\hline 1. & Aceh & 106.221 & 28.329 & 678 \\
2. & Sumatera Utara & 76.486 & 31.789 & 851 \\
3. & Sumatera Barat & 150.319 & 58.740 & 924 \\
4. & Riau & 7.629 & 3.631 & 751 \\
5. & Kepulauan Riau & 9 & 1 & 263 \\
6. & Jambi & 2.082 & 512 & 584 \\
7. & Sumatera Selatan & 10.218 & 2.837 & 760 \\
8. & Kep. Bangka Belitung & 816 & 151 & 659 \\
9. & Bengkulu & 13.517 & 4.672 & 756 \\
10 & Lampung & 63.317 & 25.507 & 934 \\
\hline & Indonesia & $\mathbf{1 . 7 4 0 . 6 1 2}$ & $\mathbf{7 2 0 . 8 6 2}$ & $\mathbf{8 2 1}$ \\
\hline
\end{tabular}

Sumber: Statistik Pertanian,2014 (diolah) 
Sementara untuk Jambi adalah sebesar $584 \mathrm{Kg} / \mathrm{Ha}$. Demikian juga halnya dengan luas lahan dan tingkat produksi untuk komoditi kakao ini Provinsi Jambi juga relatif tertinggal dibandingkan dengan beberapa provinsi lainnya di wilayah Sumatera. Dalam kaitannya dengan daya saing, maka kondisi ini memperlihatkan rendahnya tingkat daya saing Provinsi Jambi terhadap komoditi kakao ini.

\section{Kelapa}

Dari sisi produktivitas untuk komoditi kelapa, Provinsi Jambi memiliki produktivitas yang relatif tinggi dibandingkan dengan produktivitas nasional. Dari data yang ada pada tahun 2013 tingkat produktivitas komoditi kelapa secara nasional adalah $1.130 \mathrm{Ku} / \mathrm{H}$ sementara tingkat produktivitas Provinsi Jambi mencapai $1.230 \mathrm{Kg} / \mathrm{Ha}$. Bila kita amati lebi jauh dari sisi luas lahan dan produksi tanaman kopi Provinsi Jambi juga mempunyai potensi yang cukup besar terutama jika kita bandingkan dengan beberapa provinsi yang ada di wilayah Sumatera. Dari sisi luas lahan dan produksi Provinsi Jambi berada diurutan keempat Riau, Lampungg dan Aceh. Dalam kaitannya dengan saing maka terlihat Provinsi Jambi memiliki daya saing yang cukup tinggi untuk komoditi kelapa ini. Berikut dari Tabel 12 berikut ini dapat kita lihat secara lebih lengkap berkaitan dengan kondisi Provinsi Jambi untuk kelapa ini.

Tabel 12. Luas lahan, produksi dan produktivitas kelapa provinsi-provinsi di Sumatera Tahun 2013

\begin{tabular}{llccc}
\hline No & Provinsi & Luas Lahan $($ Ha) & Produksi (Ton) & $\begin{array}{r}\text { Produktivitas } \\
\text { (Kg/Ha) }\end{array}$ \\
\hline 1. & Aceh & 103.341 & 55.434 & 741 \\
2. & Sumatera Utara & 86.409 & 87.367 & 1.230 \\
3. & Sumatera Barat & 91.438 & 86.815 & 1.049 \\
4. & Riau & 520.260 & 427.080 & 1.204 \\
5. & Kepulauan Riau & 34.794 & 11.856 & 558 \\
6. & Jambi & 118.460 & 107.140 & 1.230 \\
7. & Sumatera Selatan & 65.308 & 59.787 & 1.170 \\
8. & Kep. Bangka Belitung & 10.848 & 6.513 & 859 \\
9. & Bengkulu & 9.645 & 8.453 & 1.284 \\
10 & Lampung & 125.438 & 113.518 & 1.082 \\
\hline & Indonesia & $\mathbf{3 . 6 5 4 . 4 7 8}$ & $\mathbf{3 . 0 5 1 . 5 8 5}$ & $\mathbf{1 . 1 3 0}$ \\
\hline
\end{tabular}

Sumber: Statistik Pertanian,2014 (diolah)

\section{Kebijakan dalam mendorong daya saing sektor pertanian Provinsi Jambi}

Analisis SWOT (strenght, weaknes, opportunities and threats) merupakan alat analisis untuk memilih dan menetapkan strategi untuk menetapkan strategi guna memaksimalkan kekuatan (strenght) dan peluang (opportunities) dan secara bersamaan berusaha untuk meminimalkan kelemahan (weaknes) dan ancaman (thereats). Dalam penelitian ini analisis SWOT ini akan digunakan sebagai dasar untuk memperkuat posisi daya saing dari sektor pertanian Provinsi Jambi, sebagaimana diberikan pada Tabel 13.

Secara umum kebijakan dapat kita artikan sebagai langkah-langkah atau tindakan yang sudah dilakukan, sedang dilakukan dan akan dilakukan oleh pemerintah dalam rangka mencapai suatu tujuan. Berdasarkan analisis SWOT, dalam konteks daya saing maka berikut ini dapat kita lihat beberapa langkah kebijakan dibidang pertanian yang dijalankan oleh pemerintah baik yang berasal dari pemerntah pusat maupun pemerintah daerah provinsi terutama yang berkaitan dengan peningkatan daya saing. Merujuk kepada RPJM bidang pangan dan pertanian tahun 2015 - 2019 beberapa kebijakan dalam rangka meningkatkan daya saing produk-produk pertanian dapat dilakukan melalui beberapa hal diantaranya meningkatkan kemampuan petani, peningktan kelembagaan, peningkatan produktivitas, peningkatan produksi, dan pendekatan klaster. 
Tabel 13. Analisa SWOT terhadap sektor pertanian Provinsi Jambi

\begin{tabular}{|c|c|}
\hline Kekuatan (Strength) & Kelemahan (Weakness) \\
\hline $\begin{array}{l}\text { - Keadaan agroklimat yang dimiliki oleh } \\
\text { Provinsi Jambi yang memungkin untuk } \\
\text { tumbuhnya berbagai jenis tanaman yang } \\
\text { akan menghasilkan berbagi komoditi, } \\
\text { terutama berbagai komoditi perkebunan } \\
\text { seperti karet, kelapa sawit, kopi, casiavera dll } \\
\text { - Tersebarnya potensi untuk sektor pertanian } \\
\text { hampir disemua daerah kabupaten yang ada. } \\
\text { - Tersedianya lahan yang cukup luas } \\
\text { khususnya untuk tanaman perkebunan. } \\
\text { - Sumber pertumbuhan ekonomi daerah, } \\
\text { penyediaan lapangan kerja dan ekonomi } \\
\text { masyarakat. }\end{array}$ & $\begin{array}{l}\text { - Masih terbatasnya infrastruktur yang dapat } \\
\text { mendorong berkembangnya sektor peranian } \\
\text { terutama irigasi, pelabuhan, jalan dan } \\
\text { infrastruktur dasar lainnya. } \\
\text { - Terbatasnya teknologi dan tingkat } \\
\text { pengetahuan serta keahlian petani baik } \\
\text { secara teknis maupun dalam pengelolaan } \\
\text { usaha. } \\
\text { - Belum banyak peranan lembaga pendukung } \\
\text { yang dapat mendorong perkembangan } \\
\text { sektor pertanian di Provinsi Jambi misalnya } \\
\text { lembaga keuangan dan lembaga penelitian. }\end{array}$ \\
\hline Peluang (Opportunity) & Ancaman (Threat) \\
\hline $\begin{array}{l}\text { - Permintaan yang cukup tinggi untuk } \\
\text { berbagai produk-produk pertanian sehingga } \\
\text { peluang pasar masih terbuka lebar. } \\
\text { - Adanya penemuan atau inovasi teknologi } \\
\text { pertanian sehingga memungkinkan } \\
\text { pengembangan beberapa produk pertanian. } \\
\text { - Kebijakan pemerintah yang tetap mendukun } \\
\text { untuk berkembangnya sektor pertanian di } \\
\text { Provinsi Jambi. }\end{array}$ & $\begin{array}{l}\text { - Semakin tingginya tingkat persaingan dari } \\
\text { beberapa produk pertanian baik secara } \\
\text { regional, nasional maupun internasional. } \\
\text { - Tingginya fluktuasi harga dari produk- } \\
\text { produk pertanian. } \\
\text { - Serangan hama yang cukup besar } \\
\text { berpengaruh terhadap t produksi pertanian. } \\
\text { - Adanya pemanasan global yang } \\
\text { berpengaruh terhadap produksi pertanian. } \\
\text { - Masih terbatasnya hilirisasi berbagai } \\
\text { produk pertanian di Provinsi Jambi. } \\
\text { - Cukup banyaknya terjadi alih fungsi lahan } \\
\text { pertanian kepada bidang diluar pertanian } \\
\text { sehingga dalam jangka panjang akan } \\
\text { menimbulkan semakin berkurangnya lahan } \\
\text { pertanian di Provinsi Jambi. }\end{array}$ \\
\hline
\end{tabular}

Sumber: Data diolah, 2014

\section{KESIMPULAN DAN SARAN}

\section{Kesimpulan}

Secara makro Provinsi Jambi relatif memiliki daya saing yang cukup tinggi untuk sektor pertanian, hal ini dapat kita lihat dari koefisien LQ sektor pertanian untuk Provinsi Jambi lebih besar dari satu, terutama untuk bidang perkebunan dan hortikultura. Secara mikro beberapa komoditi yang secara potensial memiliki daya saing yang relatif tinggi diantaranya komoditi kedelai, kentang, cabai, kopi dan kelapa terutama jik kita lihat dari sisi tingkat produktivitas, sementara karet dan kelapa sawit terutama dilihat dari sisi luas lahan dan tingkat produksi .Berdasarkan analisa SWOT untuk sektor pertanian, terlihat sektor pertanian memiliki potensi dan peluang unuk pengembangan sektor pertanian dimasa yang akan datang, namun juga memeiliki hambatan dan ancaman untuk pengembangan sektor pertanian. Dalam rangka peningkatan daya saing sektor pertanian untuk Provinsi Jambi dilakukan berbagai kebijakan diantaranya melalui peningkatan kemampuan petani, peningkatan peranan kelembagaan, peningkatan produktivitas, peningkatan produksi dan pendekatan klaster.

\section{Saran}

Untuk itu disarankan masa yang akan datang masih perlu didorong perkembangan pembangunan sektor pertanian di Provinsi Jambi baik ektensifikasi maupun intensifikasi 
sehingga daya saing sektor pertanian bisa lebih meningkat yang pada gilirannya akan dapat meningkatkan kesejahteraan petani khususnya dan peningkatan pertumbuhan ekonomi Provinsi Jambi pada umumnya.

\section{DAFTAR PUSTAKA}

Amir, A. (2007). Perekonomian Indonesia (Dalam Perspektif Makro). Biografika: Bogor.

Arifin, B. (2001).Pengembangan Ilmu Pengetahuan dan Teknologi dalam Produksi Pertanian. Dalam Arifin, B. (ed). Spektrum Kebijakan Pertanian Indonesia. Erlangga: Jakarta

Brata, S. (2003). Metodologi Penelitian. PT. Raja Grafindo Persada: Jakarta.

Chuta, E., C.Liedholm.(1984). Rural Small-Scale Industr : Emperical Evidence and policy issues. In. Eicher, C. K., and J. M. Staatz (ed). Agricultural Development in the Third World. The Johns Hopkins University Press: London

Didu, M.S. (2003).Kinerja Agroindustri Indonesia. Majalah Agrimedia VIII. 2 : 16-25. IPB: Bogor.

Endraswana, S. (2003).Metodologi Penelitian Kebudayaan. Gajah Mada University Press: Yokyakarta.

Ghatak,S., K,Ingersent. (1984).Agriculture and Economic Development.The Johns Hopkins University Press: Maryland.

Hidayat,S., Yohanes,V.A. (2007).Strategi Pengembangan Kawasan Agroindustri Terintegrasi yang berbasis Ekspor di Provinsi Jambi. Jurnal Ekonomi Regional.2(1), 1-7

Jhingan, ML. (2000).Ekonomi Pembangunan dan Perencanaan. Rajawali Press:Jakarta.

Junaidi, Amri, A., Hardiani. (2014).Potensi Klaster Agroindustri Usaha Mikro Kecil dan Menengah di Provinsi Jambi. Jurnal Perspektif Pembiayaan dan Pembangunan Daerah.2(2),9-20

Kuncoro, M. (1997). Keterkaitan Antara Sektor Pertanian dan Industri. Ekonomi Pembangunan. UPP AMP: Yokyakarta.

Mokhazani, B.A.R. (1979).Rural Development in Shoutheast Asia. Vikas Publishing House PVT LTD: New Delhi.

Mubyarto. (1989).Pengantar Ekonomi Pertanian. LP3ES: Jakarta.

Mulyana, D. (2004). Metodologi Penelitian Kualitatif. PT. Remaja Rosdakarya: Bandung.

PPSK Bank Indonesia-LP3E FE-Unpad. (2008). Profil dan pemetaan daya saing ekonomi daerah Kabupaten/Kota di Indonesia. Rajawali Pers: Jakarta.

Richard, L. (1985).Marketing of Agricultural Products.Macmillan Publishing Company: New York.

Saptana. (2010). Keunggulan Komparatif-Kompetitif dan Strategi Kemitraan. Pusat Penelitian dan Pengembangan Sosial Ekonomi. Badan Litbang Pertanian Departemen Pertanian RI: Bogor.

Silitonga, C. (1995).Kebijaksanaan pemerintah dalam pengembangan agribisnis. Majalah Pangan: VI. 24, hal. 19-28. Jakarta.

Strauss, A., Corbin, J. (2005). Dasar-dasar penelitian kualitatif. Pustaka Pelajar: Jakarta.

Zamzami., Hastuti, D. (2018). Determinan Penerimaan Daerah dan Pertumbuhan Ekonomi Terhadap Pengembangan Ekonomi Kreatif di Provinsi Jambi. Jurnal Paradigma Ekonomika. 13(1), 37-45

Zulgani, Syaparuddin, Parmadi. (2014). Analisis Daya Saing Produk Agroindustri Subsektor Perkebunan dalam Perekonomian Wilayah Provinsi Jambi. Jurnal Perspektif Pembiayaan dan Pembangunan Daerah. 2(1),29-38 